\title{
STUDENT'S PERSPECTIVE ON VIRTUAL LABORATORY USING PHET AS A MEDIA IN CONDUCTING PHYSICS LABORATORY ACTIVITIES
}

\author{
Riki Purnama Putra ${ }^{1 *}$, Rizki Amelia Anjani ${ }^{2}$, Rena Denya Agustina ${ }^{3}$, \\ Herni Yuniarti Suhendi ${ }^{4}$, Melia Pioren ${ }^{5}$ \\ 1,3,4,5 Physics Education Study Program, Faculty of Tarbiyah and Teacher Training, \\ Universitas Islam Negeri Sunan Gunung Djati, Bandung, Indonesia \\ ${ }^{2}$ Biology Education Study Program, Faculty of Tarbiyah and Teacher Training, Universitas \\ Islam Negeri Sunan Gunung Djati, Bandung, Indonesia \\ *Email: purnamariki20@gmail.com
}

Website: http://jurnal.uin-antasari.ac.id/index.php/jtjik

Received: 16 September 2020; Accepted: 2 June 2021; Published: 22 June 2021

\begin{abstract}
The purpose of writing this paper article is to review students' perceptions in the use of PhETbased virtual labs and also to provide a description in comparison to perceptions of virtual lab use from some of the results of previous studies that are relevant to this study. There are five aspects in the perception that will be surveyed, including; (1) aspects of innovation, (2) aspects of benefits (3) aspects of motivation, (4) aspects of effectiveness, (5) aspects of presenting procedures for laboratory activities. The method used is quantitative and qualitative with a Likert scale questionnaire which must be filled in by 40 people and then interviewing the subjects, after the data is collected, percentage data analysis is carried out. The results of the data analyzed show that the aspects of innovation, effectiveness, benefits and presentation of the procedure get a positive view compared to the motivational aspects which are stated to be negative, so this study also shows that the use of virtual labs based on PhET is innovative and effective, but lacks motivation in its use because of essential activities. laboratory is not felt, in presenting the module is required to increase 4C Skills to support 21st century skills.
\end{abstract}

Key Words: media; perspection; PhET; physics; virtual laboratory

\section{INTRODUCTION}

Laboratory activities are a framework of process that includes planning, discovering facts, collecting data, classifying, obtaining conclusions and interpretations, sometimes with the intention to immerse students into the process of scientific investigation (Putra et al., 2021)

The introduction of Information and Communication Technology (ICT) among educational institutions and college students has opened a new window into the world of practicum-based learning. In addition to the traditional laboratory, students can carry out or be involved in a virtual laboratory activity which is supported by a computer instead of a smartphone. Furthermore, a teacher or lecturer is required to be able to use ICT tools to show students something without any access to the actual resources.

A traditional laboratory (TL) research's objective can be defined as an active activity by using real objects and instruments to observe object and its process. If an instrument is used, an object that stands alone (independent) and cannot be utilized directly or the distance is very far, then the virtual lab is the alternative. The use of virtual labs is to enable personal computers as an interactive experimental simulation (Špernjak \& Šorgo, 2018). 
Virtual lab is a website or software for interactive learning based on simulation of real phenomena.The virtual lab allows students to explore topics by comparing and contrasting various scenarios, to do interlude and restart the application for reflection and note-taking, and to gain practical experimental experience through internet or software.

The advantages of virtual labs are: (a) flexibility in terms of time and location; (b) the results are instantly available; (c) the results are reliable; (d) repetition can be done right away; (e) no need to purchase laboratory equipment continuously; (f) safer experiments since it makes practicum with hazardous or expensive materials possible, and $(\mathrm{g})$ time-consuming experiments can be shortened (Špernjak \& Šorgo, 2018)

In 2020 online learning is widely used, so that the needs of virtual learning increases. For practicum itself, virtual labs are highly favored to collect data on laboratory activities of physics education students, especially in Basic Physics I, Basic Physics II, School Physics Laboratory, and also Thermodynamics.

During the pandemic, one of which is the CoVid-19 in 2020, the government always advises and even instructs its people to Stay At Home (SAH), Work From Home (WFH) and even Study From Home (SFH). This influences the teaching and learning process to dramatically change in terms of presentation, from face-to-face in class into virtual classroom using smartphones or other communication tools.

In Basic Physics I, Basic Physics II, School Physics Laboratory, and Thermodynamics, proper study, analysis, and laboratory procedures of various physical phenomena are necessary.

Supporting learning facilities are very important to conduct a research so that activities in studying physics phenomena can be carried out without any constraints. An alternative solution used by the Physics Education Study Program at one of the PTKINs in the city of Bandung is to use a virtual laboratory application through one of the virtual lab providers, namely PhET which is expected to solve problems regarding with practicum and provide students with laboratory experience on some physics material that requires practicum.

According to (Oidov et al., 2012), based on the results of numerical experiments on students, they are strongly encouraged to formulate important laws in physics by themselves. In general, there are two types of activities that help students to develop their thinking skills (1) by carrying out laboratory "investigations", students can make numerical measurements and estimation with computer related to physical quantities (2) later, through intensive and active discussion and debate, students interpret new facts and data in order to instill meaningful understanding within themselves. This led to the "discovery" of the basic laws or regularities of physics. Overall, the series of lab activities help students to be more involved and explore the actual results of a physical phenomenon (Putra \& Anjani, 2020).

The virtual laboratory also functions as a computer-based laboratory for physics activities, consists of hierarchical and logical learning (Abdulwahed \& Nagy, 2013) where students are able to (1) take numerical measurements and evaluate the process that is being explored (2) processing and interpreting data (information / facts) to make it meaningful to themselves through intensive discussion (3) students are able to write formulas and formulate the basic laws of physics by themselves.

The effectiveness of the use of PhET in virtual lab activities has been approved by several previous studies by (Perkins et al., 2006), (Rochmah \& Madlazim, 2013), (Prihatiningtyas et al., 2013), that (1) the PhET can explain materials whose concepts are abstract and difficult to understand compared to the lecturing method (2) compared to integrating a simple KIT, PhET is more effective in helping students understand abstract concepts because it requires a short amount of time and more practical than a KIT that must be assembled 
first (3) students' learning outcomes by using $\mathrm{PhET}$ are better than thoes who do not.

The use of virtual labs is stated to provide positive values for physics learning and laboratory activities that are abstract in nature, especially for educational institutions whose laboratory facilities do not support the process of acquiring understanding. Virtual laboratory activities at the Physics Education Study Program of UIN Sunan Gunung Djati Bandung are often carried out in several courses because the use of virtual lab simulations must be incorporated to support the use of the real lab. However, during the CoViD-19 pandemic now, students of the Physics Education study program are required to fully use the virtual lab until undetermined time. This study aims to determine students' perceptions towards the use of PhET-based virtual labs, is it innovative? Are they motivated to use it? Is it effective? Is it useful as a support for laboratory activities? And can the presentation of the laboratory activity module be understood?

\section{RESEARCH METHOD}

The method used in this study is quantitative and qualitative research, by providing online questionnaires containing questions and they must be filled in by students in the Physics Education study program of UIN Sunan Gunung Djati Bandung, including 40 people, and regarding with several aspects, researchers will interview their perceptions further. Students fill out a questionnaire when the even semester learning ends. This PhET application has been developed in a previous R\&D research. Data collection was carried out by observing students 'answers to determine students' perceptions of the PhETbased virtual lab.

Questionnaires which must be filled in by the students are given through social media such as WhatsApp and E-mail.There are 10 questions that must be filled in by the students in the questionnaire which incorporates Likert scale; Strongly Agree (SS), Agree (S), Disagree (TS), and Strongly Disagree (STS) which have been designed and carried out in previous research by Evi Suryanti, et al (Suryanti et al., 2019), consists of several aspects. These aspects can be seen in table 1 .

Table 1. Table of Research Aspects

\begin{tabular}{|c|c|c|c|c|}
\hline \multirow{2}{*}{ Aspect } & \multicolumn{2}{|c|}{ Question } & \multirow{2}{*}{$\begin{array}{c}\text { Serial } \\
\text { number }\end{array}$} & \multirow{2}{*}{$\begin{array}{c}\text { Number } \\
\text { of } \\
\text { Questions }\end{array}$} \\
\hline & Positive & Negative & & \\
\hline Inovation & 1 & 1 & 1,2 & 2 \\
\hline Motivation & 1 & 1 & 3,4 & 2 \\
\hline Effectivity & 1 & 1 & 5,6 & 2 \\
\hline Benefit & 1 & 1 & 7,8 & 2 \\
\hline $\begin{array}{l}\text { Module } \\
\text { Presentation }\end{array}$ & 1 & 1 & 9,10 & 2 \\
\hline Total & 5 & 5 & & 10 \\
\hline
\end{tabular}

The results of the questions that have been filled in by the students are calculated by using the percentage formula proposed by Sugiono, the formulation is:

$P=\frac{f}{N} \times 100 \%$ (Sugiyono, 2013)
With Description:

$\mathrm{P} \quad=$ Total Value (Percent) of Respondents

$\mathrm{f} \quad=$ Frequency of the answer

$\mathrm{N} \quad=$ Number of Respondents 
In the questionnaire, the questions are in the form of positive and negative

The percentages from scales 4 and 3 are added and interpreted as positive perceptions, whereas those of scales 2 and 1 are added and interpreted as negative perceptions, and the opposite applies to negative questions, where "SS" and "S" are interpreted as negative perceptions, "TS" and "STS"are interpreted as positive perceptions.

\section{RESULTS AND DISCUSSIONS}

In this study, students who will be observed will use a PhET-based virtual lab with parabolic motion and hooke's law. The students carry out laboratory activities based on the inquiry guided laboratory module that has been made and verified by previous media and material experts. When they have carried out virtual laboratory activities with PhET media, students are given a questionnaire and also being interviewed. Then the results of the 5 aspects which are the main focus can be seen in table 1 . The results of the research are presented in tabular form quantitatively from several aspects which can be seen in table 2 .

Table 2. Percentage of 5 Research Aspects

\begin{tabular}{lccc}
\hline \multirow{2}{*}{ Aspek } & \multicolumn{2}{c}{ Percentage (\%) } & \multirow{2}{*}{ Total (\%) } \\
\cline { 2 - 3 } & Positive & Negative & \\
\hline Inovation & 66.25 & 33.75 & 100 \\
\hline Motivation & 47.5 & 52.5 & 100 \\
\hline Effectivity & 76.25 & 23.75 & 100 \\
\hline Benefit & 68.75 & 31.25 & 100 \\
\hline Module & 82.5 & 17.5 & 100 \\
Presentation & & & \\
\hline
\end{tabular}

The quantitative results in table 2 show that the four aspects give positive results and one aspect, the Motivation aspect, gets negative results. The results in table 2 will be explained qualitatively based on each aspect.

\section{Inovation Aspect}

On the innovation aspect (Questions 1 and 2), as many as $66.25 \%$ of students considered the use of PhET in laboratory activities to be very efficient and also easier to understand in terms of its utilizations, benefits, and also the results it obtained. As many as $33.75 \%$ of students considered the use of PhET to be less than optimal in terms of innovation, where they noticed that the data generated would be the same, and they also considered the application of PhET in laboratory activities is only for validation.

These results are also in line with the one of research conducted by (Supurwoko et al., 2017) that the use of PhET is declared innovative by students, because students can understand abstract concepts such as photoelectric effect material easily because there are supporting animations and they can use virtual lab easily and less complicated. The use of PhET media as a virtual laboratory activity is believed to be innovative, as stated by Putry (Putry et al., 2017), the pre-test and post-test data show that students can meet the criteria of critical thinking frameworks, and also students' responses to $\mathrm{PhET}$ media as a very innovative tool to support learning and laboratory activities without laboratory equipment.

\section{Motivation Aspect}

On the motivation aspect (Questions 3 and 4), as many as $47.5 \%$ of the students were motivated to use PhET-based virtual labs, and as many as $52.5 \%$ of the students were not motivated to use PhET-based virtual labs.

The results found turned out to be different from previous research that had 
been conducted by Evi, (Suryanti et al., 2019). Evi said that in her findings, with 28 research objects, it was shown that $96 \%$ of students showed positive values and $4 \%$ of students showed negative values. The results obtained were also different from the findings by Prima (Prima et al., 2018) with the results obtained were $69.87 \%$ positive for student motivation in using PhET-based virtual labs.

When researchers found different results from previous studies, the researcher asked this question further to several students who gave negative results, when the interview took place, the researcher concluded that (1) students feel less optimality in using virtual labs; (2) the results obtained will always be the same as the others; (3) partners in laboratory activities are considered to be detrimental to one of the parties, those who say, "The PhET virtual lab has been designed. If we include certain variables, the results will be already determined. So, the use of PhET is only for verification. There are no supporting factors as in the real lab". It turns out that many PhET-based virtual lab users in Physics Education Study Program of UIN Sunan Gunung Djati Bandung are still not motivated to use PhET to conduct lab activities. They prefer to use real lab because they can directly see and operate the tools which will give them real experience.

Furthermore, the researchers directly asked several people who responded positively regarding with motivation to use a PhET-based virtual lab. They were more motivated because its usage was simple and did not take much time. Just by clicking, they got accurate data results. It can also be repeated many times without entering the laboratory building.

This matter is also reinforced by a research conducted by Špernjak and Šorgo (Špernjak \& Šorgo, 2018). The results of research from Špernjak and Šorgo state that students do not like the use of virtual labs because everything is set up perfectly and students only need to click the button that has been provided on the computer. As the result, the user feels more saturated. Dyrberg (Dyrberg et al., 2017) in his research states that students are not too enthusiastic and motivated when they use virtual laboratories because they do not acquire freedom to explore due to the very limited features of the virtual lab.

\section{Effectivity Aspect}

On the aspect of effectiveness (Questions 5 and 6), a total of $76.25 \%$ of students stated that the use of a PhET-based virtual lab was effective, and also $23.75 \%$ of students stated that the use of a PhETbased virtual lab was not effective.

The results of perception of linear effectiveness with research that has been previously done by Majorie Darrah (Darrah et al., 2014) where in the previous research conducted on students who showed the results that the use of virtual labs was more effective compared to real labs.

This is because the virtual lab is easier to use, and also time-efficient, but what is more superior than the use of a virtual lab is also that the data obtained will be available immediately and does not need to take up a lot of space (Sulistiowati et al., 2013). However, unlike Dalgarno's research (Dalgarno et al., 2009), in his research, the results showed that the use of virtual laboratories was less appealing to younger generation $(<25$ years of age and currently pursuing undergraduate education). As many as $49 \%$ of the total subjects felt the use of virtual laboratory does not worth their time since the result will always be the same. However, older generation recognizes its usefulness (aged 25-40 years and currently studying at the master's level). As much as $51 \%$ of the total subjects went through different experiences in terms of the effectiveness related to time management when collecting data for theory/concept validation.

\section{Benefit Aspect}

On the aspect of benefit (questions 7 and 8), as many as $68.75 \%$ of students 
stated that the virtual lab had benefits for them, and also $31.25 \%$ of students stated that the virtual lab had no benefits for them.

The researcher further interviewed several students to get clarity on the benefits they get when using a virtual lab, as well as to clarify the lack of benefits of the lab. Based on the results of all interviews that have been conducted, the researcher concludes that the benefits of this PhETbased virtual lab are: (1) simple User Interface display; (2) time-efficient (3) availability of abstract concepts' visualization; (4) easy to use and can be done many times; (5) does not take up much space; (6) instructions to obtain data are very easy to understand; (7) problemsolving can be improved because they can solve it without being constrained (Subali et al., 2017). However, those who feel there is no benefit for them because they cannot use the virtual lab. It is due to the absence of a tutorial from the lecturer and insufficient knowledge to process the data that has been obtained (Arista \& Kuswanto, 2018)

The results of the benefits aspect have been carried out and are in line with previous research by Tiina Lynch and Ioana Ghergulescu (Lynch et al., 2018) in that study, they used STEM-based virtual labs in visualizing abstract concepts. They found and revealed that the use of virtual labs in learning activities and laboratory activities can support educators and students.

Research on the benefits of using virtual labs compared to real labs has been carried out by Malah Abou Faour (Faour et al., 2018) in his journal, he suggests that the benefits of using virtual labs include: (1) the use of teaching methods (virtual laboratory or interactive demonstration using a real lab) improves students' conceptual understanding; (2) Its utilization has a very significant effect compared to the interactive demonstration method incorporating real laboratory equipment; (3) the use of virtual laboratories does not affect attitudes more than actual laboratory practices; (4) the use of virtual laboratories increases students' perceptions of their teachers' attitudes towards them as students.

\section{Module Presentation Aspect}

On the aspect of module presentation (questions 9 and 10), as many as $82.5 \%$ of students revealed that the presentation of modules for laboratory activities using PhET as a virtual laboratory media was complete, clear, concrete. It also improves communication skills when pouring out the results. However, there are $17.5 \%$ of students who have a negative view toward module presentation. This is because $17.5 \%$ of the them think that they do not understand the modules used in virtual-based laboratory activities.

Improving communication skills is very necessary in the presentation of modules because the module is a medium to convey the results of laboratory activities. In the research conducted by S Sapriadil, et al (Safitri et al., 2019), they reveal that in higher order thinking virtual laboratory (HOTVL), during virtual laboratory activities, communication skills must be strengthened. Therefore, there is no confusion throughout the activities. The practicum module must enhance communication skills so that students can easily process and communicate their findings/research.

Improvement of Critical Thinking Skills is also very much needed when presentating the module. According to Kukreti in his research (Kukreti et al., 2002), the flow of the virtual lab is still considered to be applied as a cookbook laboratory does not meet the standard to improve Critical Thinking Skills. Therefore, module presentation should support the development of students' critical thinking frameworks before using the virtual laboratory. According to Tzafestas (Tzafestas et al., 2006), it seems that virtual laboratory only serves the verification purpose. Therefore, the improvement of critical thinking must begin with the presentation module of laboratory activities. 
Based on the results of the data found by the researchers, the presentation of the module is very important as an initial step of laboratory activities. Hence, we suggest other researchers to conduct research on modules presentation that may improve 4C Skills that support 21 st century skills. In addition, we recommend researchers to think about student output results when they carry out laboratory activities.

\section{CONCLUSION}

In accordance with the results of the data that have been analyzed in the discussion, it is concluded that in the aspects of innovation, effectiveness, benefits, and procedures presentation for laboratory activities, there are positive results from the view of students from Physics Education Study Program of UIN Sunan Gunung Djati Bandung, on the use of virtual laboratories with PhET media for laboratory activities. However, on the motivational aspect, there are still many students of the Physics Education Study Program at UIN Sunan Gunung Djati Bandung who view it negatively. This can be solved if the lecturer design more attractive virtual lab activities. This finding can also be used as a foundation to develope a virtual lab with PhET media in physics laboratory activities.

Overall, it shows that the use of PhET-based virtual labs is innovative and effective, but motivation aspect needs to be improved throughout its use because the students are unable to obtain the essentials of laboratory activities. In presenting the module, it is important to improve 4C Skills that support 21 st century skills.

\section{REFERENCES}

Abdulwahed, M., \& Nagy, Z. K. (2013). Developing the TriLab, a triple access mode (hands-on, virtual, remote) laboratory, of a process control rig using LabVIEW and Joomla. Computer Applications in Engineering Education, 21(4), 614-626. https://doi.org/10.1002/cae.20506

Arista, F. S., \& Kuswanto, H. (2018). Virtual physics laboratory application based on the android smartphone to improve learning independence and conceptual understanding. International Journal of Instruction, 11(1), 1-16. https://doi.org/10.12973/iji.2018.1111 a

Dalgarno, B., Bishop, A. G., Adlong, W., \& Bedgood, D. R. (2009). Effectiveness of a Virtual Laboratory as a preparatory resource for Distance Education chemistry students. Computers and Education, 53(3), 853865.

https://doi.org/10.1016/j.compedu.200 9.05.005

Darrah, M., Humbert, R., Finstein, J., Simon, M., \& Hopkins, J. (2014). Are Virtual Labs as Effective as Hands-on Labs for Undergraduate Physics? A Comparative Study at Two Major Universities. Journal of Science Education and Technology, 23(6), 803-814. https://doi.org/10.1007/s10956-0149513-9

Dyrberg, N. R., Treusch, A. H., \& Wiegand, C. (2017). Virtual laboratories in science education: students' motivation and experiences in two tertiary biology courses. Journal of Biological Education, 51(4), 358-374. https://doi.org/10.1080/00219266.201 6.1257498

Faour, M. A., Ayoubi, Z., \& The, Z. (2018). The Effect of Using Virtual Laboratory on Grade 10 Students' Conceptual Understanding and their Attitudes towards Physics. Journal of Education in Science Environment and Health, 4(1), 54-68. https://doi.org/10.21891/jeseh.387482

Kukreti, A. R., Zaman, M., Gramoll, K., \& Lee, J. H. (2002). Virtual laboratory modules for undergraduate strength of materials course. ASEE Annual Conference Proceedings, 1, 4865- 
4873. https://doi.org/10.18260/1-2-11280

Lynch, T., Learning, I. G.-E. I., \& undefined 2018. (2018). Innovative pedagogies and personalisation in STEM education with NEWTON Atomic Structure Virtual Lab. Learntechlib.Org, 1483-1491. https://www.learntechlib.org/p/18436 $8 /$

Oidov, L., Tortogtokh, U., \& Purevdagva, E. (2012). Virtual laboratory for physics teaching. 2012 International Conference on Management and Education Innovation, 37, 319-323. http://www.ipedr.com/vol37/062ICMEI2012-E10015.pdf

Perkins, K., Adams, W., Dubson, M., Finkelstein, N., Reid, S., Wieman, C., \& LeMaster, R. (2006). PhET: Interactive Simulations for Teaching and Learning Physics. The Physics Teacher, 44(1), 18-23. https://doi.org/10.1119/1.2150754

Prihatiningtyas, S., Prastowo, T., \& Jatmiko, B. (2013). Imlementasi simulasi phet dan kit sederhana untuk mengajarkan keterampilan psikomotor siswa pada pokok bahasan alat optik. Jurnal Pendidikan IPA Indonesia, 2(1), $18-22$. https://doi.org/10.15294/jpii.v2i1.250 5

Prima, E. C., Putri, A. R., \& Rustaman, N. (2018). Learning solar system using PhET simulation to improve students' understanding and motivation. Journal of Science Learning, 1(2), 60. https://doi.org/10.17509/jsl.v1i2.1023 9

Putra, R. P., \& Anjani, R. A. (2020). Analisis Pemahaman Siswa Kelas 12 di SMAN 1 Cileunyi terhadap pembelajaran Fisika Online selama pandemi CoVid-19. Jurnal Profesi Keguruan, 6(2), 167-173.

Putra, R. P., Silvianti, N., Idris, S. F., \& Nabilla, N. (2021). Uji Perbandingan Virtual Lab dengan Real Lab pada
Hukum Archimedes. Radiasi : Jurnal Berkala Pendidikan Fisika, 14(1), 2333.

https://doi.org/https://doi.org/10.3772 9/radiasi.v14i1.897

Putry, A. A., Pratama, A. C., \& Delima, E. (2017). Enhancing Physics Student's Achievement Through Problem Based Learning Assisted PhET on High School. Chair Person, 189.

Rochmah, N. H., \& Madlazim. (2013). Media Lab Virtual Phet Pada Materi Sub Pokok Bahasan Fluida Bergerak Di Man 2 Gresik. 02(03), 162-166.

Safitri, D., Setiawan, A., Suhandi, A., Malik, A., Sahida Lisdiani, S. A., \& Sapriadil. (2019). The Effects of Higher Order Thinking (HOT) Laboratory Design in Hooke Law on Student's Creative Thinking Skills. Journal of Physics: Conference Series, 1204(1), 0-6. https://doi.org/10.1088/17426596/1204/1/012037

Špernjak, A., \& Šorgo, A. (2018). Differences in acquired knowledge and attitudes achieved with traditional, computer-supported and virtual laboratory biology laboratory exercises. Journal of Biological Education, 52(2), 206-220. https://doi.org/10.1080/00219266.201 7.1298532

Subali, B., Rusdiana, D., Firman, H., Kaniawati, I., \& Ellianawati, E. (2017). Computer-based experiment of free fall movement to improve the graphical literacy. Jurnal Pendidikan IPA Indonesia, 6(1), 41-48. https://doi.org/10.15294/jpii.v6i1.875 0

Sugiyono. (2013). Metode Penelitian Kombinasi. In Metode Penelitian Kombinasi (1st ed.). Alfabeta. https://doi.org/10.1145/3132847.3132 886

Sulistiowati, N., Yuanita, L., Prodi, P., Sains, P., \& Negeri, U. (2013). Perbedaan Penggunaan Laboratorium Real dan Laboratorium Virtual Pada 
Keterampilan Proses dan Hasil.

Pendidikan Sains Pascasarjana

Universitas Negeri Surabaya, 2(2), 191-197.

Supurwoko, S., Cari, C., Sarwanto, S., Sukarmin, S., Budiharti, R., \& Dewi, T. S. (2017). Virtual Lab Experiment: Physics Educational Technology (PhET)Photo Electric Effect for Senior High School. International Journal of

Science and Applied Science: Conference Series, 2(1), 381. https://doi.org/10.20961/ijsascs.v2i1.1 6750

Suryanti, E., Fitriani, A., Redjeki, S., \& Riandi, R. (2019). Persepsi Mahasiswa terhadap Penggunaan Virtual Laboratory dalam Pembelajaran Biologi Molekuler. Journal of Natural Science and Integration, 2(2), 32. https://doi.org/10.24014/jnsi.v2i2.788 4

Tzafestas, C. S., Palaiologou, N., \& Alifragis, M. (2006). Virtual and remote robotic laboratory:

Comparative experimental evaluation. IEEE Transactions on Education, 49(3), 360-369.

https://doi.org/10.1109/TE.2006.8792 55 